УДК 94:351.741:331.108.644 (477.84) «1944/1948»

DOI https://doi.org/10.32838/2663-5984/2019/4.9

\title{
Пирожишин Р.В.
}

Тернопільський національний педагогічний університет імені Володимира Гнатюка

\section{ПРОСТУПКИ ТА ПОКАРАННЯ ПРАЦІВНИКІВ РАЙОННИХ ТА МІСЬКИХ ВІДДІЛЕНЬ НАРОДНОГО КОМІСАРІАТУ ДЕРЖАВНОЇ БЕЗПЕКИ - МІНІСТЕРСТВА ДЕРЖАВНОЇ БЕЗПЕКИ У ТЕРНОПІЛЬСЬКІЙ ОБЛАСТІ У 1944-1948 РОКАХ}

\begin{abstract}
У статті на основі значного обсягу історичних першоджерел та монографій досліджено питання проступків та покарань прачівників районних та міських відділень Народного комісаріту державної безпеки - Міністерства державної безпеки в Тернопільській області в 1944-1948 роках. Автор звертає увагу на основний тип покарання - ув'язнення від 3-х до 20-ти діб, догана або сувора догана. Рідше траплялися такі покарання, як пониження в посаді, переведення в інше відділення. Були й виняткові заходи, коли працівників органів державної безпеки віддавали під суд та засуджували на тривалі терміни ув'язнення. Що стосується проступків, автор зазначає, що на початковому періоді роботи органів Народного комісаріту державної безпеки, а це жовтень 1944 - лютий 1945 років, вони стосувались низьких показників у роботі. Зокрема: мала кількість завербувань інформаторів і агентів, незначна кількість затримань, мала кількість відкритих агентурних справ та завершених. Автор статті також виділяе і проступки, що стосуються порушення кримінально-прочесуального законодавства Союзу Радянських Соціалістичних Республік. Зокрема, ие стосувалось тривалого розслідування окремих справ, що перевищувало встановлені законом терміни, несвоєчасного висунення звинувачення окремим засудженим. Автор статті наголошує і на тому, що були наявніi такі форми порушення кримінально-прочесуального законодавства, як побої під час допитів. В окремий блок автор групує порушення, що були пов'язані із вживанням алкоголю та з усіма наслідками після цього: запізнення на роботу, на роботі працівник був ще або вже у стані алкогольного сп'яніння, не з'являвся на роботу взагалі, низькі показники в роботі, неприйнятна поведінка на людях і навіть смерть одного із працівників. Такі проступки карались одразу та жорстко: арештом терміном від 15-ти до 20-ти діб, пониженням у посаді, навіть переведенням на роботу в інше відділення, також віддавали працівників під суд. Автор підкреслює й те, щзо порушення, які пов 'язані із вживанням алкоголю, були частими та поширеними в багатьох районах Тернопільської області. Із введенням нової посади начальника винищувальних батальйонів також пов'язані покарання за проступки. Що стосується проступків, то автор виділяє: низькі показники в роботі, розвал і ліквідація окремих сільських батальйонів. Як покарання застосовували арешти на різні терміни.
\end{abstract}

Ключові слова: НКДБ, МДБ, оперуповноважений, начальник відділення, заступник начальника, проступки, покарання.

Постановка проблеми. Ефективність державної політики на місцях безпосередньо залежить від призначень і механізму покарань за проступки працівників служби безпеки Союзу Радянських Соціалістичних Республік (далі - СРСР), особливо коли ця держава - окупант, що намагається в умовах війни протистояти націоналістичним силам. Реалізація політики СРСР вкорінення радянської влади на західноукраїнських землях i знищення повстанського руху безпосередньо залежали від кадрової політики. Саме завдяки суворій дисципліні та продуманій системі заохочень і покарань радянська влада зуміла взяти під свій контроль українські землі. 3 огляду на це актуальності набуває вивчення теми проступків і покарання працівників районних та міських відділень Народного комісаріту державної безпеки Міністерства державної безпеки (далі - НКДБ МДБ) у Тернопільській обл. в 1944-1948 pр.

Аналіз останніх досліджень і публікацій. Дослідженню проблематики проступків і покарань працівників районних та міських відділень присвячено працю Є. Жирнова «Робота в ЧК часто розбещує» [2]. Діяльності репресивно-каральної системи в Україні в 1945-1953 рр. загалом присвячено працю І. Біласа [1]. Ю. Шаповал у своїй праці «Подполье в Западной Украине. Отечественные записки» описує діяльність органів держбезпеки 
на Західній Україні. Однак дана тематика і досі залишається недостатньо вивченою. Значна кількість праць, у яких автори в загальному описують напрями роботи НКДБ - МДБ. С. Жирнов у своїй праці описує покарання працівників держбезпеки загально по всьому СРСР, а відомості щодо Тернопільської обл. обмежуються одним абзацом. Отже, тематика залишається недостатньо дослідженою та потребує подальшого вивчення.

Постановка завдання. Мета статті полягає у висвітленні й аналізі проступків і покарань працівників районних та міських відділень НКДБ МДБ у Тернопільській обл. в 1944-1948рр. Основні завдання статті: висвітлити та проаналізувати проступки працівників держбезпеки; висвітлити та проаналізувати покарання працівників держбезпеки.

Виклад основного матеріалу дослідження. Після того як 15 квітня 1944 р. радянська армія витіснила німецьку з міста Тернопіль почалося відновлення в місті й області органів радянської влади, відновлювались і структури Народного комісаріту державної безпеки (далі - НКДБ). Водночас сюди направлялись нові кадри, перед якими ставилися чіткі завдання, за невиконання яких карали, а за виконання заохочували. Працівниками органів держбезпеки вчинялись правопорушення: дисциплінарні або кримінальні, за які вони отримували покарання.

Із жовтня 1944 р. до січня 1945 р. лейтенант держбезпеки Петро Молчанов обіймав посаду в.о. начальника Новосілківського районного відділення, на якій особливих здобутків не спостерігалось. За період перебування на посаді його відділення зуміло завербувати лише п'ять інформаторів і жодного агента. 3 уже існуючими агентами зв'язок підтримувався рідко, 3 деким не зв'язувались більше шести місяців. Зустрічі 3 агентами проводились безпосередньо в будівлі районного відділення, а не на конспіративних квартирах. За його каденції не було відкрито i не велося жодної агентурної розробки, також нікого не було заарештовано. У зв'язку із цим у 1945 р. його було заарештовано на п'ятнадцять діб та понижено до посади оперуповноваженого того ж районного відділення [3, арк. 2].

31 січня 1945 р. було знято з посади в. о. Тернопільського міського відділення НКДБ майора Олександра Прокопова та понижено до начальника районного відділення. Оскільки за чотири місяці працівники міського відділення нікого не арештували, а заведені справи й агентурні розробки не мали особливої цінності [3, арк. 8].
За період із вересня 1944 р. по лютий 1945 р. в Буданівському районі спостерігався ріст активності діяльності Організації українських націоналістів (далі - ОУН), проте працівниками районного відділення було заарештовано лише троє осіб. У зазначений період було заведено лише одну агентурну справу та чотирнадцять справформулярів. Цінних вербовок агентури не було. Такий розвал агентурно-оперативної роботи був наслідком бездіяльності начальника районного відділення Володимира Чубарєва. У зв'язку із чим він отримав сувору догану та попередження, якщо він не налагодить роботу районного відділення, то його буде знято з посади та покарано [3, арк. 15].

Проведеним у квітні місяці службовим розслідуванням було виявлено, що в Буданівському Райвідділі (далі - РВ) НКДБ агентурна робота ведеться на низькому рівні. Апарат районного відділення на чолі з начальником районного відділення Чубарєвим не займається питаннями активної боротьби з оунівським підпіллям, не має ніякої цінної агентури, з інформаторами працюють погано, у роботі проявляють благодушність, а ворогів радянської влади не репресують. За перші три місяці 1945 р. було заарештовано лише двоє осіб, за цей час не ліквідовано жодної агентурної розробки чи справи-формуляра. У районі діяв лише один агент, наявні інформатори працювали погано через бездіяльність працівників районного відділення. За невиконання директив начальника Буданівського районного відділення старшого лейтенанта Чубарєва було заарештовано на п'ять діб. Також його було попереджено, що в разі повторення ситуації його буде знято з роботи начальника районного відділення та понижено в посаді [3, арк. 38-38 зв.].

Не були одиночними випадки покарань працівників органів безпеки і за порушення кримінально-процесуального законодавства. Здебільшого ці порушення стосувались тривалого розслідування окремих справ, що перевищувало встановлені законом терміни, або ж несвоєчасного висунення звинувачень окремим засудженим. Так, 24 серпня 1944 р. було заарештовано коменданта поліції часів німецької окупації Лушного, а оперуповноважений Копиченського РВ НКДБ лейтенант Целіщев взявся розслідувати цю справу. Після двох допитів лейтенант не повертався до цієї справи п'ять місяців. Білобожницьким районним відділенням 24 листопада 1944 р. було арештовано Федорківа, що був волосним старостою в період німецької окупації. Ведучи слідство в цій справі, помічник оперуповноваженого Язиков 
допитав підозрюваного один раз, а через вісімнадцять днів відправив його в Чортківську тюрму, без пред'явлення йому звинувачень. А до цієї справи він не повертався наступні три місяці. За відсутність належного контролю за підопічними начальники Копиченського та Білобожницького районних відділень отримали догану. А оперуповноважений Целіщев і помічник оперуповноваженого Язиков були арештовані на п'ять діб із виконанням службових обов'язків [3, арк. 49-49 зв.].

Були й інші форми порушення кримінальнопроцесуального законодавства. Так, начальник Козівського РВ НКДБ Павло Заваригін під час допиту підозрюваних у справі в допомозі повстанцям ОУН дав волю кулакам, за що йому було оголошено догану. Начальнику Козлівського РВ НКДБ Івану Порфір'єву за затримку закінченої слідчої справи на термін у п'ять місяців без поважної на те причини також було оголошено догану [3, арк. 63].

Покарання можна було понести й за те, що 3'явився на роботу в нетверезому стані. 28 січня 1946 р. начальник I відділення слідчого відділу УНКДБ ст. лейтенант Данілов на вечінє чергування з'явився п'яним. Зайшовши в кабінет старшого слідчого Шмакова, який допитував арештовану Дубчак, незважаючи на відсутність даних про те, що Дубчак $є$ станичною ОУН, Данілов вимагав iï підтвердити це, на що отримав негативну відповідь і почав її бити. За те, що прийшов на роботу п'яним, та за нанесення тілесних ушкоджень Івана Данілова було арештовано на п'ятнадцять діб із виконанням службових обов'язків. Також його було попереджено, що в разі повторення таких ситуацій його будуть судити військовим трибуналом [4, арк. 12].

Заступника Копиченського РВ НКДБ Івана Брагіна за розпивання спиртних напоїв із підопічними на квартирі в інформатора й за те, що він відправив співробітників Целіщева зі Шмаковим за додатковою порцією спиртного, також було арештовано на п'ятнадцять діб без виконання службових обов'язків [4, арк. 13].

Траплялись і більш серйозні покарання, аніж арешт на кілька діб. Так, за вбивство оперуповноваженого Копиченського району ст. лейтенанта Целіщева старшого слідчого відділу УНКДБ ст. лейтенанта Прокопа Шмакова заарештовано та притягнуто до кримінальної відповідальності [4, арк. 13].

За деякі проступки інколи знімали 3 посади. Так, заступник начальника Бережанського РВ НКДБ ст. лейтенант А. Парнюгін за період роботи на вказаній посаді з 10 липня 1945 р. мав низькі показники в роботі. На додачу ним не було завербовано цінних агентів, кількість арештованих ним украй мала. Замість покращення роботи та допомоги всьому оперативному складу $\mathrm{PB}$ НКДБ А. Парнюгін випивав, через що прогулював роботу, прикриваючись поганим самопочуттям. За низькі показники в агентурно-оперативній роботі та вживання алкоголю в робочий час Андрія Парнюгіна було арештовано на п'ять діб без виконання службових обов'язків. Після відбування покарання його було відкликано з посади заступника начальника Бережанського РВ НКДБ [4, арк. 20].

Арештовували працівників і на більші терміни, аніж зазвичай (5-15 діб). Так, 30 березня 1946 р. було арештовано на двадцять діб, без виконання службових обов'язків, оперуповноваженого Лановецького РВ МДБ ст. лейтенанта Анатолія Земськова за те, що він з'явився на операцію у стані алкогольного сп'яніння, що спричинило недоречне застосування зброї на хуторі Левчук та побиття затриманої Марії Левчук. Також лейтенант часто випивав з інформатором «П», спізнювався на роботу, саме через вживання алкоголю. А ще ст. лейтенант А. Земськов передав свій бойовий пістолет «ТТ» колишньому члену ОУН Стасюку, що переїхав разом із ним до Кременця [4, арк. 32].

30 березня того ж року на двадцять діб без виконання службових обов'язків було арештовано й оперуповноваженого Новосільського РВ МДБ ст. лейтенанта Миколу Локаліна. Арештували його за фальсифікацію слідчої справи на громадянина Беркита, незаконне затримання місцевих жителів та вимагання 3 них хабарів за звільнення. Також він неодноразово випивав, коли перебував на завданнях у селах, вимагав від місцевих жителів продукти харчування для особистих потреб. Схиляв до інтимного зв'язку секретного інформатора. За свої проступки він отримав попередження, що за найменший огріх буде відданий під суд військового трибуналу. Також із зарплати М. Локаліна було компенсовано Беркиту вартість відібраних у нього речей: брюк та черевиків [4, арк. 34].

Покарання отримували не лише начальники, заступники районних відділень чи оперативний склад, але й прості вахтери. 10 липня 1946 р. було арештовано на п'ятнадцять діб без виконання службових обов'язків вахтера РВ МДБ молодшого лейтенанта Василя Остроухова. Він під час роботи в районному відділенні систематично випивав, влаштовував дебоші, вступав у зв'язки 
із сумнівними людьми. Також його було попереджено, що наступне його порушення призведе до притягнення до суду [4, арк. 92].

Карали і за не надіслану вчасно документацію. Про підсумки агентурно-оперативної роботи серед репатріантів міські та районні відділення Міністерства державної безпеки (далі - МДБ) повинні були кожного місяця звітувати згідно із вказівками УМДБ. Однак начальник Новосільського РВ МДБ майор Постнов протягом одного року не надсилав звітів узагалі. За невиконання вказівок УМДБ майора Постнова було арештовано на три доби з виконанням службових обов'язків [4, арк. 113].

Серйозні санкції щодо працівників застосовувались після комплексної ревізії районних чи міських відділень МДБ. Так, ревізія Тернопільського МВ МДБ показала, що агентурно-оперативна робота у 2-му (агентурно оперативному) відділенні ведеться на дуже низькому рівні. За минулі місяці 1946 р. співробітники відділення не мали оперативних розробок, практично не займалися виявленням та ліквідацією повстанців з ОУН, а низка об'єктів у місті не забезпечені чекістським обслуговуванням узагалі. Начальник 2-го відділення МВ МДБ Андреєв не здійснював належного контролю над підопічними, віддаючи перевагу вживанню алкоголю. Старші оперуповноважені Губарєв та Водоп'янов агентурною роботою займались рідко та безсистемно. Начальник МВ МДБ підполковник Сирцов не звертав уваги на низькі показники 2-го відділення і не вжив заходів для покращення роботи останнього. Заступник начальника MB МДБ капітан Макаров байдикував, високих показників в агентурно-оперативній роботі не мав, часто випивав, конфліктував із працівниками відділення. За ці порушення начальника 2-го відділення МB МДБ Бориса Андреєва було арештовано на десять діб та понижено до посади старшого оперуповноваженого РВ МДБ. Старшого оперуповноваженого Олександра Водоп'ятова було арештовано на п'ять діб та понижено до оперуповноваженого МВ МДБ. Старшому оперуповноваженому Івану Губарєву Івану було оголошено догану, переведено його на роботу в інший район. Матеріали про начальника Тернопільського МВ МДБ підполковника Сирцова i його заступника капітана Макарова було направлено у МДБ Української Радянської Соціалістичної Республіки для винесення рішення та притягнення їх до відповідальності [4, арк. 116-117 зв.].

Покарання можна було отримати і за халатне ставлення до роботи. Так, 7 лютого 1947 р. на п'ять діб було арештовано оперуповноваженого
Чортківського РВ МДБ лейтенанта Маслова за те, що він під час допиту арештованого «Б» у приміщенні відділення на першому поверсі залишив його самого в кабінеті, де була відкрита шафа 3 оперативними напрацюваннями, а сам покинув відділення на тривалий час [5, арк. 13].

Із появою посади начальника винищувального батальйону у штатних розписах самі батальйони почали перевіряти. Після однієї з перевірок було виявлено, що начальник штабу винищувального батальну Велико-Дедеркальського РВ МДБ капітан М. Голясний не керує на належному рівні роботою батальйону, випиває разом із бійцями батальйону. За перші шість місяців 1947 р. вони не мають ніяких оперативних результатів. Через відсутність належного управління батальйони низки сіл розпались, були ліквідовані РВ МДБ. За розвал і бездіяльність щодо керівництва групами винищувального батальйону начальника штабу винищувального батальну Велико-Дедеркальського РВ МДБ капітана Миколу Голясного було арештовано на десять діб і попереджено про його службову невідповідність [5, арк. 133].

Після перевірки винищувального батальйону Шумського РВ МДБ було виявлено, що начальник штабу старшина I. Козаков роботою з виховання та бойового згуртування бійців не займався. Систематично вживав спиртні напої, дисципліна у групах винищувального батальйону була на низькому рівні. У результаті групи сіл Сураж, Васьківці та Рахманово довів до розпаду, а керівництвом РВ МДБ їх було ліквідовано. За вказані проступки старшину I. Козакова було арештовано на п’ятнадцять діб з утриманням його на гауптвахті, попереджено про його службову невідповідність. Начальник Шумського РВ МДБ капітан Кіріченко отримав вказівку налагодити роботу винищувального батальйону [5, арк. 135].

Суттєві санкції до працівників районних відділень застосовувались після комплексних перевірок. Після проведеної перевірки у квітні 1948 р. було виявлено, що у Велико-Дедеркальському РВ МДБ оперативні показники залишаються низькими, незважаючи на значну активність повстанців ОУН у районі. Діють кілька боївок і 27 повстанціводинаків. У 1948 р. члени ОУН зуміли провести п’ять акцій, відділком було знайдено очільників лише однісї. Така ситуація була зумовлена тим, що начальник РВ МДБ майор Сорокін халатно ставився до роботи, зовсім не контролював співробітників відділення. За це йому було оголошено сувору догану, а також попереджено, що в разі невиконання серпневих і квітневих вказівок про- 
тягом місяця до нього будуть застовані серйозніші санкції [6, арк. 35-35 зв.].

Згідно з результатами перевірки Заложецького РВ МДБ від 9 липня 1948 р., у старшого оперуповноваженого Петра Молчанова спостерігаються низькі показники в роботі, із серпня 1947 р. і до моменту перевірки ним не було заведено жодної оперативної розробки, не було жодного арешту. За таку бездіяльність лейтенанта П. Молчанова було арештовано на десять діб і понижено до оперуповноваженого [6, арк. 49].

За порушення законів СРСР, що виразилось у неправомірному арештом таємного агента МДБ «Шевченко», унаслідок чого його довгий час утримували під арештом, начальника Золотопотоцького РВ МДБ капітана Івана Чепелевича було арештовано на п'ять діб із виконанням службових обов'язків і попереджено, що в разі повторення таких ситуацій його покарання буде жорсткіше [6, арк. 62].

Окремо варто виділити справу колишнього начальника Шумського РВ МДБ Афанасія Кириченка, якого було притягнуто до кримінальної відповідальності за підозрою в убивстві громадянки Дворецької в 1947 р. Судом військового трибуналу 22 жовтня 1948 р. ухвалено рішення, за яким Афанасія Кириченка засуджено на двадцять п’ять років позбавлення волі за вбивство громадянки Дворецької. Його було позбавлено звання майора й усіх державних нагород, а також позбавлено права обіймати державні посади [6, арк. 73].
Висновки. Отже, на початковому етапі роботи органів НКДБ (жовтень 1944 - лютий 1945 рр.) ми спостерігаємо низку дисциплінарних покарань, як-от: арешт від п'яти до п'ятнадцяти діб, догана та пониження в посаді. Усі ці санкції стали можливі через невиконання наказів, халатне ставлення до роботи і низькі показники в роботі. Працівники порушували кримінально-процесуальний кодекс СРСР, зокрема затримували громадян без висунення обвинувачень, били під час допитів, за що до них застосовували такі санкції: догану, рідше арешт. Не були поодинокими покарання працівників за вживання алкоголю та ті наслідки, які це спричиняло. Такі проступки карались жорстко, зокрема арештом до двадцяти діб, пониженням у посаді та навіть звільненням з органів держбезпеки. Притягували працівників держбезпеки і до кримінальної відповідальності за вбивство іншого працівника. Після реформи органів держбезпеки 1946 р. і створення нової посади начальника винищувальних батальйонів самі батальйони часто інспектували та перевірялись. За низькі показники в роботі начальників винищувальних батальйонів арештовували на термін від десяти до п'ятнадцяти діб. Прецедентом варто виділити справу А. Кириченка, якого було засуджено на двадцять п'ять років ув'язнення. Окремо варто зазначити попередження, працівників часто попереджували, що в разі повторення проступків чи невиконання наказів наступне покарання буде суворішим, або ж взагалі працівника буде віддано під суд.

\section{Список літератури:}

1. Білас І. Репресивно-каральна система в Україні 1917-1953 pр. Київ : Либідь, 1994. 433 с.

2. Жирнов С. Робота в ЧК часто розбещує. Закон і бізнес. 2008. № 51. С. 88-92.

3. Совершенно секретные приказы УНКДБ по Тернопольской обл. 1945 г. // Галузевий державний архів СБУ в Тернопільській обл. Ф. 1. Оп. 1. Т 1. С. 1.83 арк.

4. Совершенно секретные приказы УНКДБ по Тернопольской обл. 1946 г. // Галузевий державний архів СБУ в Тернопільській обл. Ф. 1. Оп. 1. Т 1. С. 2. 144 арк.

5. Совершенно секретные приказы УМГБ по Тернопольской обл. 1947 г. // Галузевий державний архів СБУ в Тернопільській обл. Ф. 1. Оп. 1. Т 5. С. 3.246 арк.

6. Совершенно секретные приказы УМГБ по Тернопольской обл. 1947 г. // Галузевий державний архів СБУ в Тернопільській обл. Ф. 1. Оп. 1. Т 4. С. 4. 116 арк.

7. Шаповал Ю. Подполье в Западной Украине. Отечественные записки. 2007. № 1 (34). С. 14-32.

\section{Pyrozhyshyn R.V. MISDEMEANORS AND PUNISHMENTS OF WORKERS OF REGIONAL AND CITY DEPARTMENTS OF NKGB-MSS IN THE TERNOPIL REGION IN 1944-1948}

The article deals with the issue of misdemeanors and punishments of employees of the NKD-MDB regional and city departments in Ternopil region in 1944-1948 on the basis of a considerable circle of historical sources and monographs. The author draws attention to the main type of punishment-imprisonment from 3 to 20 days and reprimand or severe reprimand. Dismissal, transferring to another department were less likely to occur. There were also exceptional measures in which state security officials were adjudicated and sentenced to long terms of imprisonment. Concerning misdemeanors, the author notes that during the initial period of work of the NKDB authorities, namely October 1944 - February 1945, they were concerned with low performance. 
Specifically: low number of informants and agents recruited, small number of detentions, or small number of opened and completed agent cases. The author also identifies misdemeanors concerning violations of criminal procedure law of the USSR. In particular, this involved a lengthy investigation of individual cases that exceeded the statutory deadlines or the late indictment of individual convicts. The author also points out that there were also forms of violation of criminal procedure law, such as beatings during interrogations. In a separate block, the author forms violations related to alcohol consumption and all the consequences thereafter: being late for work, at work the employee was still, or already in a state of alcohol intoxication, did not appear for work at all, low performance at work, unacceptable behavior on people, and even the death of one of the employees. Such misdemeanors were punished at once and cruelly: arrest for a term of 15 to 20, dismissal, and even transfer to work in another department or adjudicated. The author also emphasizes that alcohol-related disorders were common and widespread in many areas of the Ternopil region. With the introduction of the new post, the chief of the fighter battalions also made misdeeds and punishments. Concerning misdemeanors, the author emphasizes: low performance, the collapse and elimination of individual village battalions. Arrests of various terms were used as punishment.

Key words: NKGB, MSS, operative, chief of department, deputy chief, misdemeanors, punishment. 